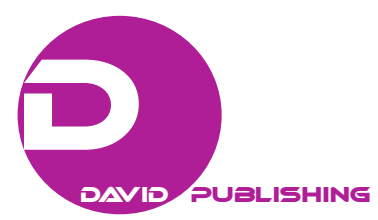

\title{
Health Care Expenditure Inequality Associated With Pollution in China
}

\author{
Pengfei Sheng \\ Henan University, Kaifeng, China
}

\begin{abstract}
This research builds an index to describe the inequality in health care expenditure related to pollution, and the measurement with Chinese provincial data set suggests that health care expenditure inequality related to pollution is obvious negative, which confirms that residents located in high-polluted areas cannot get the better health care resources. Meanwhile, the absolute value of health care expenditure inequality related to pollution is even larger than that related to income, which suggests the inequality related to pollution cannot be ignored.
\end{abstract}

Keywords: health care expenditure, inequality, pollution

\section{Introduction}

China's Gini coefficient is 0.462 in 2015, which indicates that income inequality is of increasing severity, and the most important factor affecting income inequality is the rising inequality in health care expenditure in China. Meanwhile, China's rising health care expenditure inequality is closely related to the pollution, which can do much damage to human's health. Thus, it is valuable to measure the health care expenditure inequality related to pollution.

A number of literatures consider that health inequality would be affected by many factors, such as the difference in social economic status (Lowry \& Xie, 2009), the accessibility of medical care service (Evans \& Kantrowitz, 2002), the different education level (Glied \& Lleras-Muney, 2008), and so on. However, there are few researches discussed the relationship between pollution and health inequality. As suggested by Cropper (1981), pollution would promote the depreciation of health human capital, and many empirical studies argued that pollution can do much damage to residents' health and increase their health care expenditure (Narayan \& Narayan, 2008; Coneus \& Spiess, 2012; Janke, 2014). Although pollution would cause the same damage on any resident's health, residents would make the unequal decision on health care expenditure. The unequal decision is on account of different resident's constraints, such as income, education, the accessibility of medical care resources, and so on. Thus, the inequality in health care expenditure would be affected by pollution.

The prior researches indicate that health care expenditure inequality is obviously correlated with pollution. Meanwhile, pollution and health care expenditure inequality are both important factors affecting economic

\footnotetext{
Acknowledgements: This research was supported by the Youth Foundation of Humanities and Social Sciences of the Ministry of Education in China [grant number 15YJCZH139].

Pengfei Sheng, Ph.D., associate professor, Postdoctoral Center for Studies on Advanced Statistics, Henan University, Kaifeng, China.

Correspondence concerning this article should be addressed to Pengfei Sheng, School of Economics, Henan University, the North Part of Jinming Street, Kaifeng 475002, China.
} 
development and social stability in China and other developing countries, and the two problems cannot be solved independently. In this paper, our research tries to provide an index to measure the inequality in health care expenditure related to pollution, and the measurement with China's provincial data set of the urban residents can provide some important implications for the policies to reduce pollution and alleviate the inequality in health.

\section{Method and Data}

\section{Method}

The concentration coefficient is often used to measure the inequality in health (Wagstaff, Van Doorslaer, \& Watanabe, 2003; Islam, Gerdtham, Clarke, \& Burstrom, 2010), and this index can take the bivariate distributions into account. Therefore, this research also uses the concentration coefficient to build the index to measure the health care expenditure inequality related to pollution. In the way provided by Kakwani, Wagstaff, and Van Doorslaer (1997), the concentration coefficient can be set as equation (1), and this index takes both the health distribution and the pollution distribution into account.

$$
C H P=\frac{2}{N \mu_{h}} \sum_{i=1}^{N} h_{i} P_{i}-1
$$

where, $C H P$ denotes the health care expenditure inequality related to pollution, $N$ is the number of the units in the sample, $\mu_{h}$ is the average level by health care expenditure, $h_{i}$ is the health value for the $i^{\text {th }}$ province. $P_{i}$ is the rank for the $i^{\text {th }}$ unit at the degree of the pollution, and the rank is measured by the percentage and weighted by the province's urban population.

Regarding to the index of $C H P$, its negative value suggests that the health care expenditure inequality may be benefit to the residents located in the less-polluted region, which means the residents in the less-polluted areas can get the better medical care resources and have the better health status. When the value of $C H P$ is positive, this indicates that residents located in the more-polluted areas can have the better health status.

\section{Data}

In this paper, the research conducts a Chinese provincial data set of urban residents to measure the health care expenditure inequality related to pollution. Since pollution would do the same damage to all the residents located in one region, and then it is feasible choose the urban residents of one province as one group. This choice may underestimate the real health inequality related to pollution in China, because it ignores the inequality among the residents in one province. However, it is also preferable because all cities in the same province should accept the same policies on pollution reduction and health care in China.

The data set in this research covers China's 30 provinces $^{1}$ over the period 2005-2014. Health is measured by the health care expenditure per capita, which is derived from the urban household survey carried by China's official statistics bureau. Pollution is described by the emissions of the main pollutants, which comprise the emission of sulfur dioxide in waste gas per capita, the emission of nitrogen oxide in waste gas per capita, and the emission of smoke dust in waste gas per capita. Urban population is calculated by the permanent residents located in the urban area of one province. The data set is collected from China Statistical Yearbook and China Environment Yearbook, and Table 1 reports the main descriptive statistics.

\footnotetext{
${ }^{1}$ Due to the data availability, Hongkong, Makou, Taiwan, and Tibet are excluded from the sample in this paper.
} 
Table 1

Descriptive Statistics

\begin{tabular}{|c|c|c|c|c|c|c|}
\hline Variable & Description & Unit & Mean & Max & Min & $\begin{array}{l}\text { Coefficient of } \\
\text { variance }\end{array}$ \\
\hline \multirow[t]{2}{*}{ Health } & $\begin{array}{l}\text { Per capita health care } \\
\text { expenditure }\end{array}$ & RMB per capita & 886.91 & 2327.60 & 326.46 & 0.37 \\
\hline & $\begin{array}{l}\text { Per capita emission of } \\
\text { sulfur dioxide }\end{array}$ & $\begin{array}{l}\text { Ton per } 100 \text { thousand } \\
\text { persons }\end{array}$ & 127.82 & 1147.95 & 11.89 & 1.49 \\
\hline \multirow[t]{2}{*}{ Pollution } & $\begin{array}{l}\text { Per capita emission of } \\
\text { nitrogen oxide }\end{array}$ & $\begin{array}{l}\text { Ton per } 100 \text { thousand } \\
\text { persons }\end{array}$ & 206.85 & 2438.87 & 9.34 & 1.86 \\
\hline & $\begin{array}{l}\text { Per capita emission of } \\
\text { smoke dust }\end{array}$ & $\begin{array}{l}\text { Ton per } 100 \text { thousand } \\
\text { persons }\end{array}$ & 168.79 & 2246.85 & 14.04 & 1.87 \\
\hline Urban population & $\begin{array}{l}\text { Permanent residents in } \\
\text { the urban area }\end{array}$ & 100 thousand persons & 146.19 & 1469.84 & 4.34 & 1.92 \\
\hline
\end{tabular}

\section{Results and Discussion}

By using the equation (1), Table 2 reports the health care expenditure inequality related to pollution with China's provincial data set of the urban over the sample period 2005-2014. Meanwhile, we also calculate the health care expenditure inequality related to income, and the comparison with the two indexes can help to examine whether the health care expenditure inequality to pollution is severe and important.

Following the results in Table 2, it is found that all values of health care expenditure inequality related to pollution are negative. The negative health care expenditure inequality related pollution indicates that there is an obvious gap in health care expenditure among the residents located in areas with different degrees of pollution. Meanwhile, the negative value also suggests that the residents located in high-pollution areas cannot get the better medical care resources. Thus these residents would have the worse health in short- and long-run. Over the period 2005-2014, the health care expenditure inequality related to pollution shows an upward trend, which means that residents located in high-polluted areas become worse and worse in health care. Regarding to the health care expenditure inequality related to income, the value is positive and suggests that the wealthier residents can get the better health care resources. However, results also shows that health care expenditure inequality related to pollution is larger than that related to income at the provincial level ${ }^{2}$, and this demonstrates that health care expenditure inequality related to pollution cannot be ignored, and policies on health care should pay more attention to the health inequality related to pollution.

As Grossman and Krueger (1994) argue that pollution is highly corrected with income, and then the pollution distribution should conclude some information in income distribution. When the same information is big enough, the measurement of health care expenditure related to pollution would not be efficient. Table 3 reports the correlation coefficient between pollution and per capita disposable income, and results income the two variables are correlated. However, their correlation coefficients range from 0.022 to 0.467 , and are not big enough, thus it is concluded that measurement on the health care expenditure inequality should be of efficiency and can describe the actual status in China.

\footnotetext{
${ }^{2}$ Results cannot provide the evidence that health inequality related to pollution is larger than that related to income in the whole, because our measurement does not take the inequality within the province into account.
} 
Table 2

Health Care Expenditure Inequality Related to Pollution in China

\begin{tabular}{|c|c|c|c|c|}
\hline \multicolumn{4}{|c|}{ Health care expenditure inequality related to pollution } & \multirow{2}{*}{$\begin{array}{l}\text { Health care expenditure inequality } \\
\text { to income } \\
\text { Per capita disposable income }\end{array}$} \\
\hline $\begin{array}{l}\text { Reference } \\
\text { indexes }\end{array}$ & $\begin{array}{l}\text { Per capita emission of } \\
\text { sulfur dioxide }\end{array}$ & $\begin{array}{l}\text { Per capita emission of } \\
\text { nitrogen oxide }\end{array}$ & $\begin{array}{l}\text { Per capita emission of } \\
\text { smoke dust }\end{array}$ & \\
\hline 2005 & -0.0944 & -0.0982 & -0.0405 & 0.0447 \\
\hline 2006 & -0.1038 & -0.0992 & -0.0499 & 0.0473 \\
\hline 2007 & -0.1198 & -0.1254 & -0.0758 & 0.0744 \\
\hline 2008 & -0.1231 & -0.0717 & -0.1001 & 0.0792 \\
\hline 2009 & -0.1436 & -0.0972 & -0.1289 & 0.0931 \\
\hline 2010 & -0.1569 & -0.1260 & -0.1318 & 0.1057 \\
\hline 2011 & -0.1451 & -0.1374 & -0.1185 & 0.0883 \\
\hline 2012 & -0.1450 & -0.1382 & -0.1480 & 0.1192 \\
\hline 2013 & -0.1546 & -0.1509 & -0.1350 & 0.1123 \\
\hline 2014 & -0.1400 & -0.1551 & -0.1137 & 0.0970 \\
\hline
\end{tabular}

Table 3

Correlation Coefficient Between Pollution and per Capita Disposable Income

\begin{tabular}{llll}
\hline Pollution indexes & $\begin{array}{l}\text { Per capita emission of sulfur } \\
\text { dioxide }\end{array}$ & $\begin{array}{l}\text { Per capita emission of nitrogen } \\
\text { oxide }\end{array}$ & Per capita emission of smoke dust \\
\hline 2005 & -0.143 & 0.022 & -0.423 \\
2006 & -0.179 & 0.200 & -0.439 \\
2007 & -0.195 & 0.170 & -0.427 \\
2008 & -0.205 & 0.130 & -0.434 \\
2009 & -0.240 & 0.057 & -0.467 \\
2010 & -0.277 & -0.014 & -0.408 \\
2011 & -0.344 & -0.172 & -0.432 \\
2012 & -0.346 & -0.205 & -0.424 \\
2013 & -0.321 & -0.204 & -0.368 \\
2014 & -0.334 & -0.228 & -0.367 \\
\hline
\end{tabular}

\section{Conclusions}

Although pollution can make the same damage to residents' health, residents would make different decisions on health care expenditure because they are at different levels of income, education, the accessibility of health care resources, and so on. Thus, the inequality in health care expenditure is closely correlated with pollution. By using the method of concentration coefficient, this paper tries to provide an index to describe the inequality in health care expenditure related to pollution, and conducts a China's provincial data set of the urban residents with the period 2005-2014. The results indicate that the inequality in health care expenditure is negative, which means that residents can get the better health status and use more health care resources when they are located in less-polluted areas. Moreover, the inequality related to pollution is even larger than that related to income by the absolute value, and this confirms that health care expenditure related to pollution cannot be ignored, and policies on health should take the pollution difference into account in China.

\section{References}

Coneus, K., \& Spiess, C. K. (2012). Pollution exposure and child health: Evidence for infants and toddlers in Germany. Journal of Health Economics, 31(1), 180-196. 
Cropper, M. L. (1981). Measuring the benefits from reduced morbidity. The American Economic Review, 71(2), 235-240.

Evans, G. W., \& Kantrowitz, E. (2002). Socioeconomic status and health: The potential role of environmental risk exposure. Annual Review of Public Health, 23(1), 303-331.

Glied, S., \& Lleras-Muney, A. (2008). Technological innovation and inequality in health. Demography, 45(3), $741-761$.

Grossman, G. M., \& Krueger, A. B. (1994). Economic growth and the environment. Quarterly Journal of Economics, 110(2), 353-377.

Islam, M. K., Gerdtham, U., Clarke, P., \& Burstrom, K. (2010). Does income-related health inequality change as the population ages? Evidence from Swedish panel data. Health Economics, 19(3), 334-349.

Janke, K. (2014). Air pollution, avoidance behaviour and children's respiratory health: Evidence from England. Journal of Health Economics, 38, 23-42.

Kakwani, N., Wagstaff, A., \& Van Doorslaer, E. (1997). Socioeconomic inequalities in health: Measurement, computation, and statistical inference. Journal of Econometrics, 77(1), 87-103.

Lowry, D., \& Xie, Y. (2009). Socioeconomic status and health differentials in China: Convergence or divergence at older ages? Research Report. Population Studies Center, University of Michigan.

Narayan, P. K., \& Narayan, S. (2008). Does environmental quality influence health expenditures? Empirical evidence from a panel of selected OECD countries. Ecological Economics, 65(2), 367-374.

Wagstaff, A., Van Doorslaer, E., \& Watanabe, N. (2003). On decomposing the causes of health sector inequalities with an application to malnutrition inequalities in Vietnam. Journal of Econometrics, 112(1), 207-223. 